\title{
Evaluation of immediate soft tissue changes after rapid maxillary expansion
}

\author{
Ki Beom Kim', Daniel Adams², Eustaquio A. Araújo³, Rolf G. Behrents ${ }^{4}$
}

Objective: To evaluate immediate soft tissue changes following rapid maxillary expansion (RME) in growing patients, using cone beam computed tomography (CBCT). Methods: Twenty-three consecutive patients (10 male, 13 female) treated by RME were selected. Patients were scanned using CBCT prior to placement of the rapid maxillary expander $\left(\mathrm{T}_{0}\right)$, then immediately following full activation of the appliance ( $\mathrm{T}_{1}$ ). Defined landmarks were then located on the pre- and post-treatment orientated images. Change in landmark position from pre- to post-treatment was then measured. In addition to landmarks, 10 direct measures were made to determine distance change without regard to direction to measure soft tissue change of the lips. Results: Significant transverse expansion was measured on most soft tissue landmark locations. All the measures made showed significant change in the lip position with a lengthening of the vertical dimension of the upper lip, and a generalized decrease of anterior-posterior thickness of both the upper and lower lips. Conclusions: Significant changes in the soft tissue do occur with RME treatment. There is a transverse widening of the midface, and a thinning of the lips.

Keywords: Palatal expansion technique. Cone beam computed tomography. Corrective orthodontics.

Objetivo: avaliar as mudanças imediatas no tecido mole após a expansão rápida da maxila (ERM) em pacientes em fase de crescimento, usando tomografia computadorizada de feixe cônico (TCFC). Métodos: vinte e três pacientes (10 do sexo masculino e 13 do feminino) tratados com ERM foram selecionados. Os pacientes foram escaneados por TCFC antes da implantação do expansor maxilar $\left(\mathrm{T}_{0}\right)$ e imediatamente após a completa ativação do aparelho $\left(\mathrm{T}_{1}\right)$. Pontos cefalométricos definidos foram localizados nas imagens pré- e pós-tratamento. As mudanças de posição desses pontos do pré- para o pós-tratamento foram, então, analisadas. Adicionalmente aos pontos, 10 medições diretas foram realizadas para determinar a mudança nas distâncias - independentemente da direção - nos tecidos moles dos lábios. Resultados: uma expansão transversal significativa foi notada na maioria dos pontos demarcados em tecido mole. Todas as medições apresentaram mudança significativa na posição labial, com um aumento da dimensão vertical do lábio superior e uma redução generalizada da espessura anteroposterior dos lábios inferior e superior. Conclusão: de fato, mudanças significativas do tecido mole ocorrem no tratamento com ERM. Há um alargamento transversal do terço médio da face e um afinamento dos lábios.

Palavras-chave: Técnica de expansão palatal. Tomografia Computadorizada de Feixe Cônico. Ortodontia corretiva.

${ }^{1}$ Assistant Professor, Saint Louis University.

${ }^{2}$ Private practice, Mesa, Arizona, EUA.

${ }^{3}$ Professor Department of Orthodontics Saint Louis University.

${ }^{4}$ Professor and Chair Department of Orthodontics Saint Louis University.

How to cite this article: Kim KB, Adams D, Araújo EA, Behrents RG. Evaluation of immediate soft tissue changes after rapid maxillary expansion. Dental Press J Orthod. 2012 Sept-Oct;17(5):157-64.

\begin{abstract}
Submitted: January 26, 2011 - Revised and accepted: August 15, 2011
» Patients displayed in this article previously approved the use of their facial and intraoral photographs.
\end{abstract}

» The authors report no commercial, proprietary, or financial interest in the products or companies described in this article.

Contact address: Ki Beom Kim

3320 Rutger Street, Saint Louis, MO 63104, USA

E-mail:kkim8@slu.edu 


\section{INTRODUCTION}

Rapid maxillary expansion (RME) has been shown to produce an increase in arch width and perimeter to allow correction of posterior crossbites and provide space to alleviate crowding of the dentition. ${ }^{1,2,3}$ The hard tissue changes that take place have been well documented in the literature., ${ }^{1,2,-10}$

Compared with the large amount of information available about the hard tissue changes associated with RME, there is a relatively small amount of information available regarding soft tissue changes. Karaman et al evaluated soft tissue changes induced by RME. They used lateral cephalograms taken on 20 patients pre- and post-RME treatment. They found that the nose tip and soft tissue A point followed the anterior movements of the maxilla and maxillary incisors. ${ }^{11}$

Available studies, however, largely neglect structures lateral to the midline. Studies of soft tissue change involving facial regions lateral to the midline are limited partly because these structures are not identifiable on traditional two-dimensional cephalograms. ${ }^{12}$ Also it is somewhat difficult to identify soft tissue landmarks reliably due to the nature of these tissues. ${ }^{13,14}$

One attempt to measure regions lateral to the midline in RME cases was made by Berger et al. ${ }^{15}$ They measured facial changes based on measurements made from two dimensional digital photos and found changes in several areas. Using this method they documented some changes that take place in the soft tissue when viewed from a frontal view.

With more information becoming available through the more widespread use of Cone Beam Computed Tomography (CBCT) in orthodontics, there are greater opportunities for study of the effects orthodontic treatment on the soft tissues. Progress in software development now allows for better manipulation and viewing of the CBCT images, which permits the collection of information that is reliable and precise. ${ }^{16}$

The purpose of this study was to evaluate the immediate soft tissue effects of RME using CBCT.

\section{MATERIAL AND METHODS}

Records of 25 patients were collected from an orthodontic private practice, which were consecu- tively treated with RME. All patients had been diagnosed with a skeletal transverse discrepancy, or arch length discrepancy and undergone RME treatment according to a standard protocol and performed by a single orthodontist.

Exclusion criteria consisted of patients with severe skeletal asymmetry, including those with craniofacial anomalies. Patients who had orthodontic treatment before treatment with RME were also excluded.

Because of the exclusion criteria, the final sample consisted of 23 patients (10 male, 13 female). The mean age of the patients at the time of the first CBCT image was $12.3 \pm 2.6$ years, with a range of 8.3 to 17.8 years. The second CBCT image was taken a mean of 22.8 days later with a range of 14 to 37 days.

Each patient had been treated with a fixed rapid maxillary expander. The expander used in all cases was manufactured by Dentaurum (Dentaurum Group, Ispringgen, Germany) and contained a $7 \mathrm{~mm}$ expansion jackscrew. The stainless steel appliance was soldered to orthodontic bands on the maxillary first molars, with supporting arms extending anteriorly to the premolar and canine regions (Fig 1).

The rapid palatal expander was activated two onequarter turns ( $0.2 \mathrm{~mm}$ each quarter turn) upon delivery of the appliance, then by one one-quarter turn twice a day by the patient or parent until the required

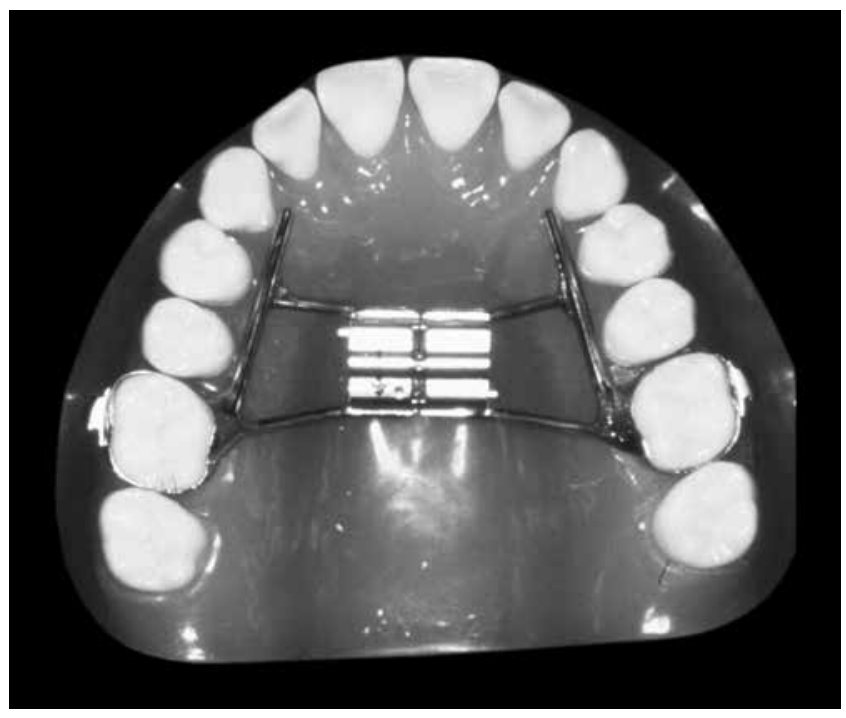

Figure 1 - Model of palatal expander used on patients in this study. 
expansion was achieved. Each patient received two CBCT scans, one prior to the delivery of the appliance $\left(\mathrm{T}_{0}\right)$, and one immediately following the active expansion phase of treatment $\left(\mathrm{T}_{1}\right)$. All scans were taken by the same technician with the patient seated in a vertical position. The patients were stabilized with teeth together in centric relation, and with the Frankfort horizontal plane parallel to the floor. The Classic i-CAT CBCT scanner (Imaging Sciences International, Hatfield, PA) was used for all scans, and required 20 seconds for each scan, with voxel size set at $0.4 \mathrm{~mm}$. Each data set was assigned a number to eliminate the possibility of patient identification and imported to Dolphin Imaging 10.5 software (Dolphin Imaging and Management Solution, Chatsworth, $\mathrm{CA})$. The image was orientated along the mid-sagittal plane (z plane), Frankfort horizontal plane (x plane), and a coronal plane (y plane) extending through the anterior wall of the right and left external meatus. The image was orientated first to the mid-sagittal plane (determined by nasion and sella), then the horizontal plane was created perpendicular to the sagittal plane and rotated until it was parallel to and aligned with Frankfort horizontal plane. Finally the coronal plane was created perpendicular to the two already established planes, and set against the anterior wall of the right external meatus (Fig 2).

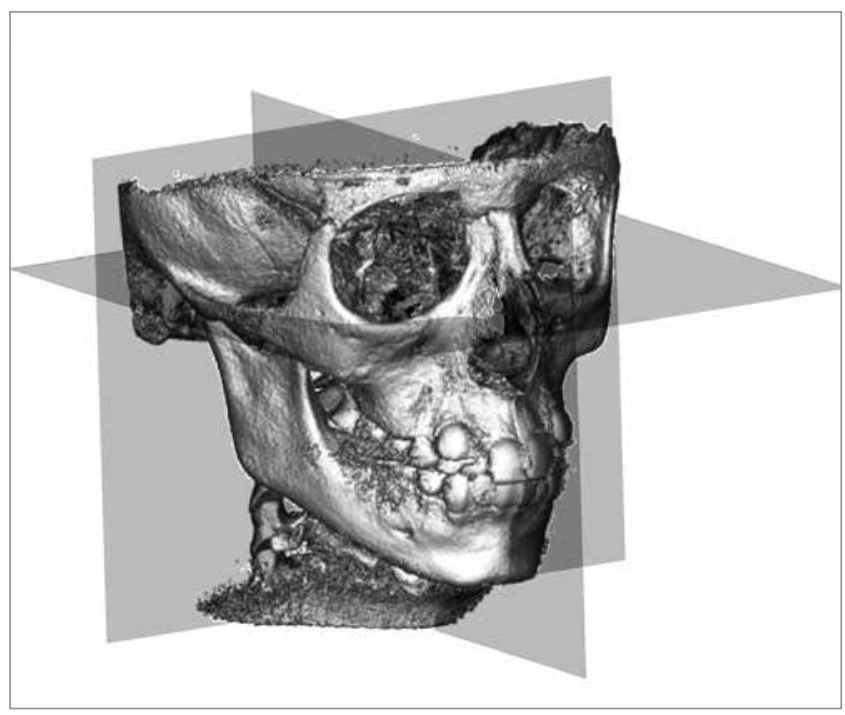

Figure 2 - Standard orientation using three-dimensional planes.

\section{Landmark assessment}

Placement of landmarks was accomplished using Dolphin Imaging software. This allows for points to be defined three-dimensionally using $\mathrm{x}, \mathrm{y}, \mathrm{z}$ Cartesian coordinate system, based on the 3 planes of orientation. A series of 20 landmarks were placed on each pre- and post-treatment scan and their threedimensional changes were determined by their $\mathrm{x}, \mathrm{y}$, $\mathrm{z}$ coordinates (Fig 3 ). The landmark at the tip of the nose was located on only 8 patients because it was not captured in the field of view on the other 15 patients.

Most of the landmarks change noted as the result of treatment was measured in the transverse plane. To detect changes in the transverse plane, the $\mathrm{x} \mathrm{co-}$ ordinate values were used. To measure anteroposterior change the $\mathrm{z}$ coordinate values were used. A list and definition of all the landmarks placed can be found on Table 1, this table also shows the plane of measurement used for each landmark.

In addition to the landmarks, 10 direct measures were made between two defined points. One direct measure was also made on the post-treatment image of the mesial and distal aspects of the rapid palatal expander to assure expansion had taken place. These measures show the change in distance between two points without regard to the direction of change. All but one of these measures was made using

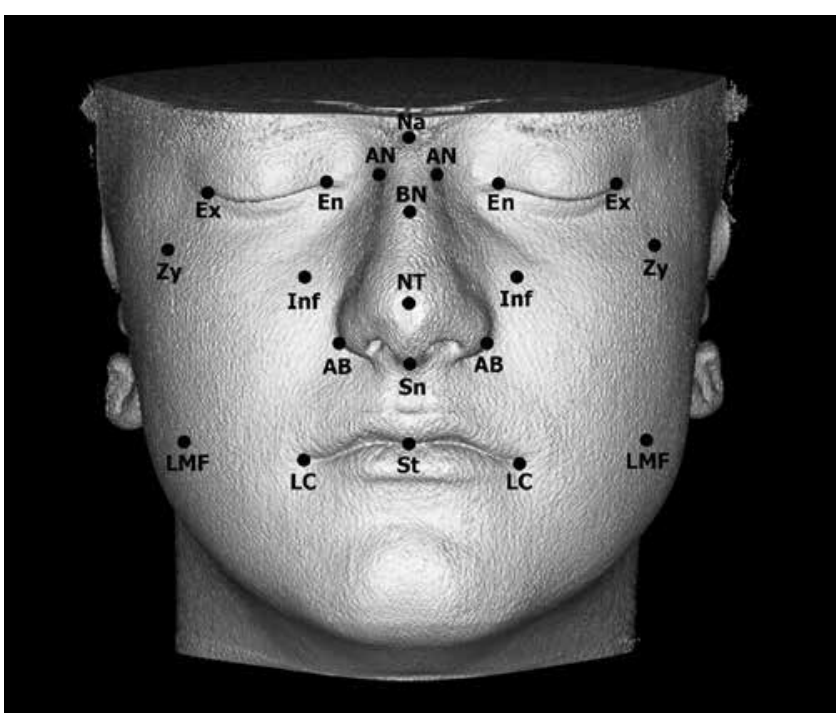

Figure 3 - Frontal view with soft tissue landmarks. 
Table 1 - Definitions of anatomic landmarks.

\section{Landmark}

Exocanthion (Ex)

Endocantion (En)

Apex of nose (AN)

Soft tissue nasion $(\mathrm{Na})$

Soft tissue zygion (Zy)

Bridge of Nose (BN)

Soft tissue over infraorbital foramen (INF)

Alar base $(A B)$

Nose tip (NT)

Subnasale (Sn)

Lower midface (LMF)

Lip commissure (LC)

Stomion (St)

\section{Definition}

Measured plane

Lateral commissure of the eye recorded bilaterally

Medial commissure of the eye, recorded bilaterally

Soft tissue over the junction of the nasomaxillary suture and nasofrontal suture, recorded bilaterally

Point of intersection between the sella-nasion line and the soft tissue profile

Soft tissue over most lateral point of the zygomatic arch, point determined from frontal view, recorded bilaterally

Soft tissue on mid-sagittal plane over the tip of the nasal bone, extended parallel to FH plane

On frontal view located the superior anterior extent of the infraorbital foramen, landmark placed on soft tissue over that point, extended parallel to $\mathrm{FH}$ plane, recorded bilaterally

Viewed frontal and inferiorly where nasal alar meets face on the inferior border of nose, recorded bilaterally

Most anterior point of the nose recorded on the mid-sagittal plane

Point at which the nasal septum merges, in the mid-sagittal plane, with the upper lip

Soft tissue over the center of the upper first molar crown, extending perpendicular from the mesiodistal plane of the crown, recorded bilaterally

Point of union of the upper and lower lip, recorded bilaterally

Median point of the mouth when the mouth is closed a two-dimensional axial image generated from the three-dimensional CBCT image. These axial images were created parallel to the Frankfort horizontal plane at the level of the centers of the crowns of the incisors in the mandible and maxilla. These were used to measure changes in the thickness of the upper and lower lips. Five measures were made on the upper lip; one measure at the mid-sagittal, and one over each of the four maxillary incisors. This measurement was taken by determining the mesiodistal axis of each tooth and constructing a perpendicular bisector from the tooth

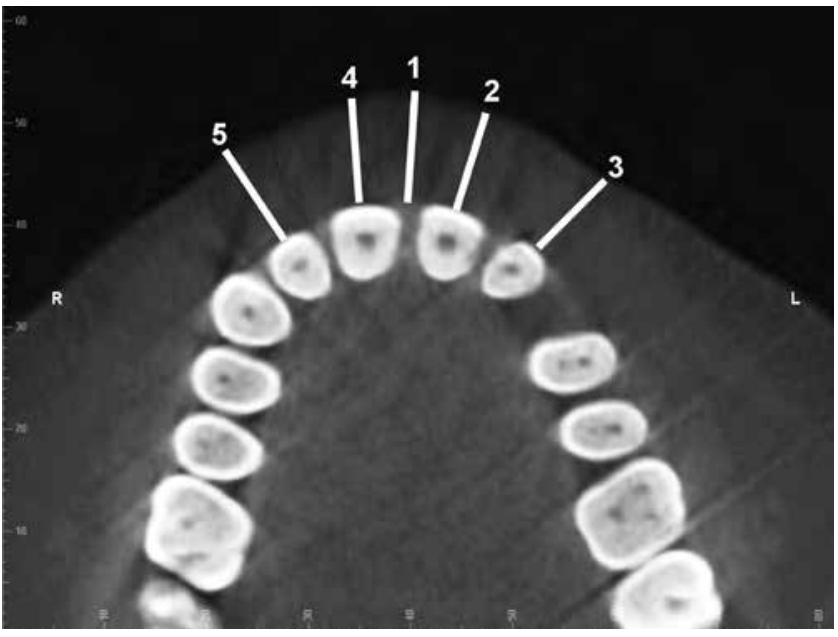

Figure 4 - Measurements of the upper lip thickness: 1) midsagittal plane 2) left central incisor, 3) left lateral incisor, 4) right central incisor, 5) right lateral incisor. outwardly to a point on the soft tissues. (Fig 4). There were four similar measures taken on the lower lip one over each mandibular incisor (Fig 5). The tenth measurement was taken on the frontal view of the threedimensional image of the soft tissues between subnasale and stomion. This measurement was used to assess changes in the vertical length of the upper lip. All of the measures taken were recorded in millimeters. The change was then averaged for five measures on the upper lip and the four measures on the lower lip to describe the average change in the thickness of each lip.

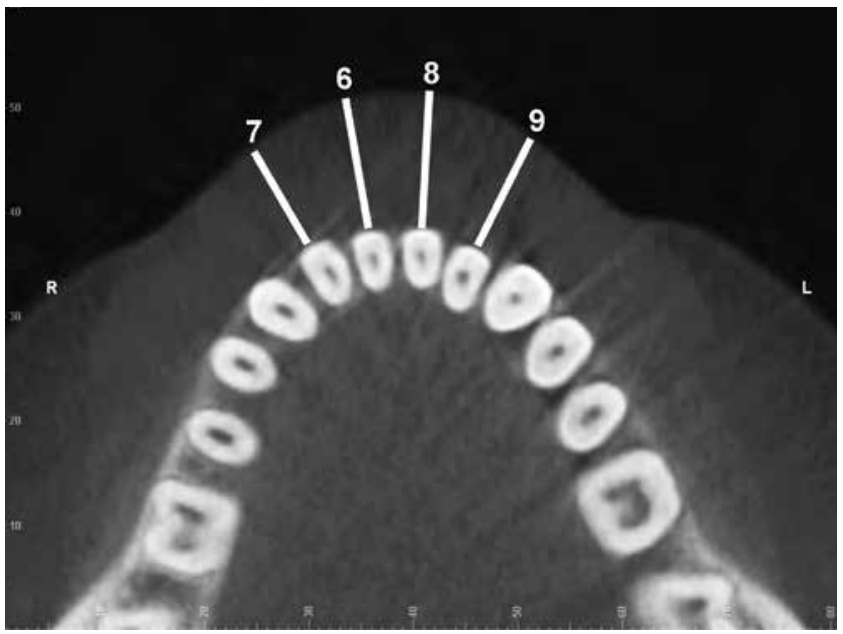

Figure 5 - Measurements of the lower lip thickness: 6) right central incisor, 7) right lateral incisor, 8) left central incisor, 9) left lateral incisor. 


\section{Statistics}

For the landmark-based assessments, measurements describe the amount of change in the specific plane being investigated. Direct measures between landmarks describe the absolute amount of change between the two points independent of the direction of change. All statistics were calculated using SPSS 14.0 Statistical Software (SPSS, Inc., Chicago, IL). In order to determine the significance of described changes, a paired t-test was used. The level of significance was defined as $\mathrm{p}<0.05$.

To asses the accuracy of landmark placement and repeated measures reliability testing was performed. Three of the twenty-three patients were randomly selected and all landmarks and measurements were duplicated. A Cronbach's alpha test was executed on repeated measures. A perfect score equals 1.00, while a Cronbach's alpha greater than or equal to 0.80 is considered an indicator for a reliable technique. Reliability testing was also used to determine the accuracy of the method of orientation. This was calculated by placing landmarks in non-changing areas of the skull, in this case on the anteriosuperior border of the right and left foramen ovale.

\section{RESULTS}

All landmarks had a Cronbach's alpha above 0.80 . The intraclass correlation coefficient showed all the landmarks to be reliable. The lowest of the Cronbach's Alpha measurements reported was 0.84 for subnasale. Reliability testing of the orientation method using the Cronbach's alpha showed the $\mathrm{x}$ and $\mathrm{z}$ alignments to be reliable; the $\mathrm{y}$-axis was not show to be reliably located. No measures were taken using the y-axis in this study.

The mean amount of RME in this sample was 5.2 $\mathrm{mm}$ with a range of $3.1 \mathrm{~mm}$ to $6.4 \mathrm{~mm}$. The descriptive statistics for all measures are listed in Table 2. The results of the paired t-tests are shown in Table 3. The measurements for all but four of the landmarks show significant changes (Figs 6 and 7). The four landmarks that did not show significance were soft tissue nasion (Na), the left lip commissure (LC), the right apex of nose (AN), and the right soft tissue over the upper first molar (LMF). All of the measured values for the lips showed a significant change.
The average change of the upper lip was then calculated by taking the mean of the changes seen with the five measures on the upper lip. The average change in thickness of the upper lip was $-0.92 \mathrm{~mm}$. The same measure was made in the lower lip and change in thickness was calculated to be $-1.04 \mathrm{~mm}$. These demonstrated a mean decrease in upper and lower lips thickness.

\begin{tabular}{|c|c|c|}
\hline Measure (mm) & $\mathbf{n}$ & Mean change \\
\hline Right Ex & 23 & $0.90 \pm 1.18$ \\
\hline Right En & 23 & $1.30 \pm 1.17$ \\
\hline Left En & 23 & $1.22 \pm 1.76$ \\
\hline Left Ex & 23 & $1.08 \pm 1.24$ \\
\hline Right LC & 23 & $1.20 \pm 1.45$ \\
\hline Left LC & 23 & $0.65 \pm 1.52$ \\
\hline Right $A B$ & 23 & $0.86 \pm 0.73$ \\
\hline Light $A B$ & 23 & $0.93 \pm 0.87$ \\
\hline $\mathrm{Na}$ & 23 & $0.43 \pm 1.24$ \\
\hline BN & 23 & $0.79 \pm 1.36$ \\
\hline Sn & 23 & $2.21 \pm 1.23$ \\
\hline Right AN & 23 & $0.43 \pm 1.25$ \\
\hline Left AN & 23 & $0.89 \pm 1.06$ \\
\hline Right Inf (Transverse) & 23 & $0.85 \pm 1.00$ \\
\hline Right Inf (Anterioposterior) & 23 & $1.21 \pm 1.56$ \\
\hline Left Inf (Transverse) & 23 & $1.12 \pm 0.97$ \\
\hline Left Inf (Anterioposterior) & 23 & $0.96 \pm 1.27$ \\
\hline NT & 8 & $1.58 \pm 0.68$ \\
\hline Right LMF & 23 & $0.78 \pm 1.89$ \\
\hline Left LMF & 23 & $1.49 \pm 1.28$ \\
\hline Right Zy & 23 & $0.88 \pm 0.65$ \\
\hline Left Zy & 23 & $1.10 \pm 1.28$ \\
\hline Sn to St & 23 & $0.92 \pm 1.04$ \\
\hline Upper Lip Midsagittal & 23 & $-1.07 \pm 0.93$ \\
\hline Upper Lip Left Central & 23 & $-0.68 \pm 0.70$ \\
\hline Upper Lip Left Lateral & 23 & $-0.77 \pm 0.84$ \\
\hline Upper Lip Right Central & 23 & $-0.93 \pm 0.98$ \\
\hline Upper Lip Right Lateral & 23 & $-1.16 \pm 1.22$ \\
\hline Lower Lip Right Central & 23 & $-0.99 \pm 1.06$ \\
\hline Lower Lip Right Lateral & 23 & $-1.07 \pm 1.06$ \\
\hline Lower Lip Left Central & 23 & $-1.19 \pm 1.01$ \\
\hline Lower Lip Left Lateral & 23 & $-0.89 \pm 1.05$ \\
\hline
\end{tabular}


Table 3 - Paired t-test results ( ${ }^{\star}$ : significance $p<0.05$ ).

\begin{tabular}{|c|c|c|}
\hline Measure & $\mathbf{t}$ & Sig. (2-tailed) \\
\hline Right Ex & 3.66 & $0.001^{\star}$ \\
\hline Right En & 5.34 & $0.000^{\star}$ \\
\hline Left En & 3.32 & $0.003^{\star}$ \\
\hline Left Ex & 4.16 & $0.000^{\star}$ \\
\hline Right LC & 3.96 & $0.001^{\star}$ \\
\hline Left LC & 2.06 & 0.052 \\
\hline Right $A B$ & 5.63 & $0.000^{\star}$ \\
\hline Left $A B$ & 5.19 & $0.000^{\star}$ \\
\hline $\mathrm{Na}$ & 1.66 & 0.111 \\
\hline $\mathrm{BN}$ & 2.69 & $0.014^{\star}$ \\
\hline $\mathrm{Sn}$ & 8.63 & $0.000^{\star}$ \\
\hline Right AN & 1.68 & 0.107 \\
\hline Left AN & 4.02 & $0.001^{\star}$ \\
\hline Right Inf (Transverse) & 4.08 & $0.000^{\star}$ \\
\hline Right Inf (Anterioposterior) & 3.73 & $0.001^{\star}$ \\
\hline Left Inf (Transverse) & 5.53 & $0.000^{\star}$ \\
\hline Left Inf (Anterioposterior) & 3.62 & $0.002^{\star}$ \\
\hline Nose Tip & 6.61 & $0.000^{\star}$ \\
\hline Right LMF & 1.99 & 0.060 \\
\hline Left LMF & 5.59 & $0.000^{\star}$ \\
\hline Right Zy & 6.56 & $0.000^{\star}$ \\
\hline Left Zy & 4.12 & $0.000^{\star}$ \\
\hline Sn to St & 4.25 & $0.000^{\star}$ \\
\hline Upper Lip Midsagittal & -5.48 & $0.000^{\star}$ \\
\hline Upper Lip Left Central & -4.65 & $0.000^{\star}$ \\
\hline Upper Lip Left Lateral & -4.37 & $0.000^{\star}$ \\
\hline Upper Lip Right Central & -4.59 & $0.000^{\star}$ \\
\hline Upper Lip Right Lateral & -4.56 & $0.000^{\star}$ \\
\hline Lower Lip Right Central & -4.46 & $0.000^{\star}$ \\
\hline Lower Lip Right Lateral & -4.86 & $0.000^{\star}$ \\
\hline Lower Lip Left Central & -5.65 & $0.000^{\star}$ \\
\hline Lower Lip Left Lateral & -3.94 & $0.001^{\star}$ \\
\hline
\end{tabular}

\section{DISCUSSION}

The changes associated with RME in hard tissue structures have been described by many authors. ${ }^{1,2,4-10}$ It has been shown that the soft tissue does not necessarily follow the changes of the underlying hard tissue. ${ }^{17}$ Studies on the soft tissue regions lateral to the mid-line are also limited partly because these structures are not identifiable on traditional two-dimensional cephalograms. ${ }^{12}$ Further it is difficult to repeatedly identify soft tissue landmarks due to the nature of these tissues. ${ }^{12,13}$

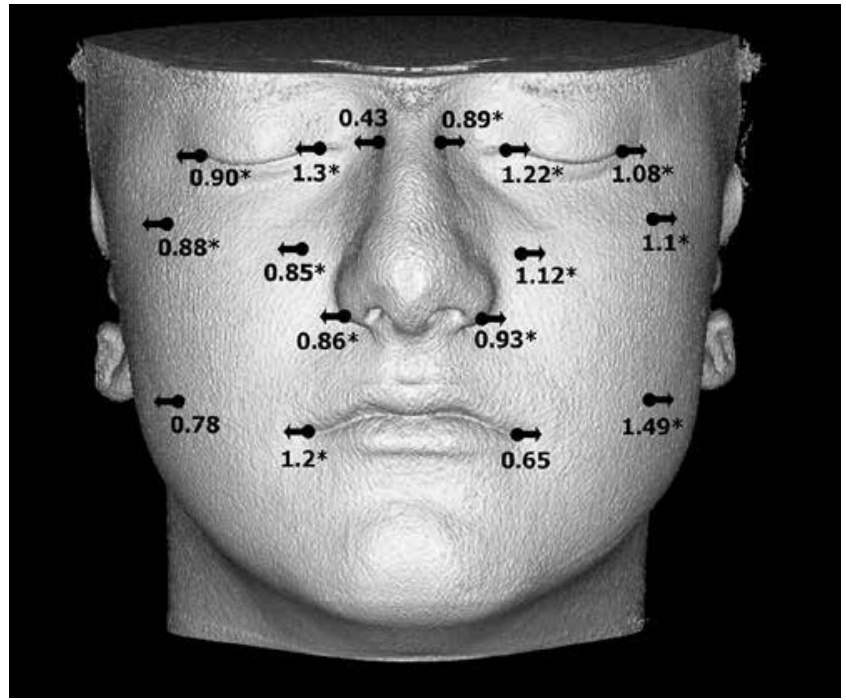

Figure 6 - Transverse change of landmarks ( ${ }^{\star}$ significant change).

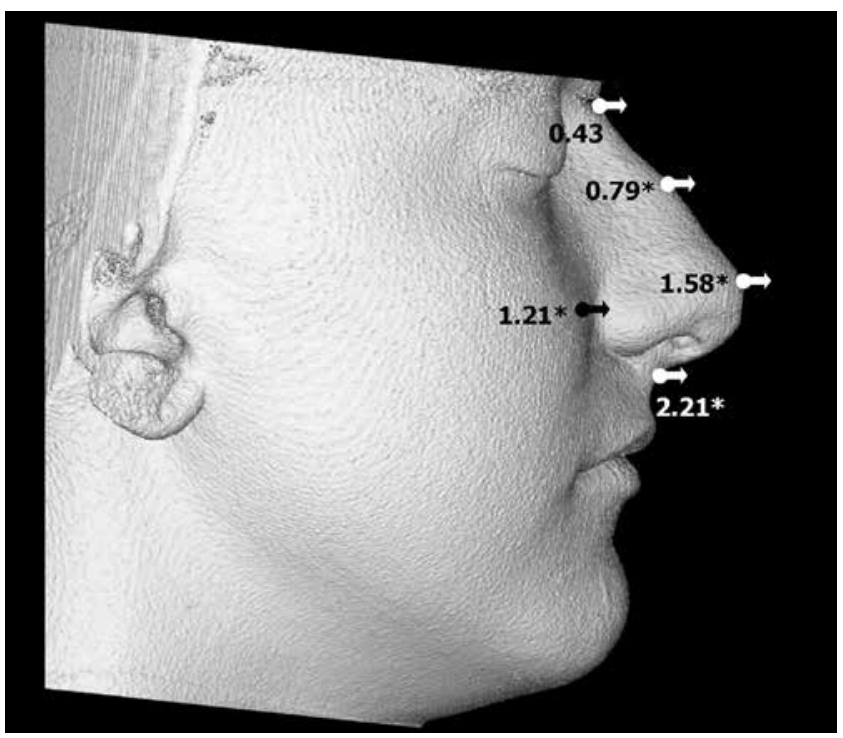

Figure 7 - Anteroposterior change ( ${ }^{\star}$ significant change).

Based on the results of this study the methods that were used to identify landmarks have shown to be reliable. Also the methods used to orientate the pre- and post-treatment CBCT scans to the same orientation have shown to be reliable. The ability to orientate the $\mathrm{T}_{0}$ and $\mathrm{T}_{1}$ images to the same orientation allowed changes to be measured in any plane.

This sample was unique in that the data provide information directly prior to placement of the appliance, and directly following the active 
expansion phase of treatment, allowing the assessment of immediate changes, directly attributed to RME. The mean time between the scans was 22.8 days with a range of 14 to 37 days. Even though the sample represents growing children, the effects of growth are negligible because of the short time between the $\mathrm{T}_{0}$ and $\mathrm{T}_{1}$ scans.

Rapid maxillary expansion is designed to increase the transverse dimension of the maxilla. The forces applied act along the transverse plane. Past studies have shown that the greatest amount of change is seen in the transverse dimension., ${ }^{1,2,-10}$ The RME devices in this study produced a mean of $5.2 \mathrm{~mm}$ of expansion with a range from $3.1 \mathrm{~mm}$ to $6.4 \mathrm{~mm}$. Many of the landmarks used in this study were chosen to measure transverse change in the soft tissue corresponding to areas of underlying hard tissues that are known to experience significant transverse changes.

\section{Transverse change}

In the upper midface transverse expansion of the soft tissue did occur. Points associated with the right eye and left eye moved away from the mid-sagittal plane representing an increase in the distance between the eyes. The width of the apex of the nose also showed an increase although the landmark movement on the right was not shown to be significant. A transverse increase was also seen in the final position of both the right and left zygions.

The width of the alar base of the nose also showed an increase. Both the right and left landmarks moved away from the mid-sagittal plane. The right side moved by an average of $0.86 \mathrm{~mm}$ and the left by 0.94 $\mathrm{mm}$. Similar findings of transverse expansion was reported in the hard tissue nasal base using metallic implants by Krebs. ${ }^{8}$ The soft tissue over the infraorbital foramen showed transverse increases. The lips and lower midface also showed a transverse increase, although the right lower midface landmark and left lip commissure movements were not significant $(p=0.06$ and $p=0.052$ respectively). Significant transverse expansion has also been noted in each of these areas in the hard tissue in previous studies. ${ }^{8,10,12,18}$

The soft tissue change seen in this sample did not however represent the triangular pattern of expansion that has been reported for hard tissue., ${ }^{910}$
When seen from a frontal view the hard tissues show a triangular pattern of opening transversely with the apex located close to the maxillo-frontal suture. Transverse expansion in the soft tissue of this sample had a more vertically parallel pattern of expansion than that reported for the hard tissue in previous studies (Fig 6). ${ }^{8,9,10}$

\section{Anteroposterior change}

Some landmarks located in the mid-sagittal plane also showed significant change. Soft tissue nasion came forward an average of $0.43 \mathrm{~mm}$ however this measure was not significant. The $p$ value of the soft tissue nasion of 0.111 showed that based on this study the change seen in this landmark was not consistent. It has been shown that the maxillary halves separate in the vertical plane in a triangular pattern with the apex near the maxillo-frontal suture with progressively with more skeletal separation inferiorly. ${ }^{9,10}$ Soft tissue nasion is located near the apex of the opening where hard tissue expansion would be expected to be minimal to none at all. Soft tissue nasion was created by extending the sella-nasion line to the soft tissue. Depending on the steepness of the sella-nasion in individual patients the landmark may possibly be higher or lower than the area where expansion occurred, which would affect the consistency of recorded results.

The bridge of the nose came forward by $0.80 \mathrm{~mm}$. The tip of the nose moved anteriorly by a mean of $1.59 \mathrm{~mm}$ however this value was only able to be measured in 8 patients because it was not captured on other scans. Subnasale moved anteriorly by a mean of $2.21 \mathrm{~mm}$. These findings are in agreement with previous findings in that there is an anterior displacement of the maxilla during RME., ${ }^{910,18,19,20}$

Anterior movement was also reported in the soft tissue over the right and left infraorbital foramina. This also would agree with reported anterior displacement of the maxillary complex that has been described with RME treatment., $, 10,18,19,20$

\section{Change in the lips}

The vertical length of the upper lip also showed to have a significant increase of $0.92 \mathrm{~mm}$. This finding agrees with Berger's study using two-dimensional digital photos which reported a mean 
increase of $1.0 \mathrm{~mm}$ immediately following the activation phase of expansion. ${ }^{15}$

The thickness of both the upper and lower lips showed a significant decrease. The upper lip changed by a mean of $-0.92 \mathrm{~mm}$, while the lower lip changed by a mean of $-1.04 \mathrm{~mm}$. This change most likely reflects the effect of transverse expansion and stretching of the soft tissue of the mouth. Although the measure of the left lip commissure for transverse expansion was not significant $(p=0.052)$ the mean was $0.65 \mathrm{~mm}$ with one outlier showing a change of $-4.6 \mathrm{~mm}$ which is likely affecting the significance. The right lip commissure showed a significant change of $1.20 \mathrm{~mm}$, showing that there is some transverse change of the lips which could account for a thinning of the lips.

This study only looked at the immediate effects of RME treatment. Many studies suggest that the effects commonly seen with RME treatment have a high level of relapse..$^{3,8,9,10,15,20,21,22}$ Future studies on this topic may look at relapse after a period of time to determine the long term stability of the observed changes.

\section{CONCLUSIONS}

Significant changes in the soft tissue do occur with RME. There is a transverse widening of the midface, and a decrease of the thickness of the upper and lower lips.
1. Gryson JA. Changes in mandibular interdental distance concurrent with rapid maxillary expansion. Angle Orthod. 1977;47:186-92.

2. Adkins MD, Nanda RS, Currier GF. Arch perimeter changes on rapid palatal expansion. Am J Orthod Dentofacial Orthop. 1990;97:194-9.

3. Geran RG, McNamara JA, Jr., Baccetti T, Franchi L, Shapiro LM. A prospective long-term study on the effects of rapid maxillary expansion in the early mixed dentition. Am J Orthod Dentofacial Orthop. 2006;129:631-40.

4. Cross DL, McDonald JP. Effect of rapid maxillary expansion on skeletal, dental, and nasal structures: A postero-anterior cephalometric study. Eur J Orthod. 2000;22:519-528.

5. Davis WM, Kronman JH. Anatomical changes induced by splitting of the midpalatal suture. Angle Orthod. 1969;39:126-32

6. Haas A. Gross reactions to the widening if the maxillary dental arch of the pig by splitting the hard palate. Am J Orthod. 1959;45:868.

7. Haas A. Rapid expansion of the maxillary dental arch and nasal cavity by opening the midpalatal suture. Angle Orthod. 1961;31:73-90.

8. Krebs A. Midpalatal Suture Expansion Studies by the Implant Method over a Seven-Year Period. Rep Congr Eur Orthod Soc. 1964;40:131-42.

9. Wertz R, Dreskin M. Midpalatal suture opening: A normative study. Am J Orthod. 1977;71:367-81.

10. Wertz RA. Skeletal and dental changes accompanying rapid midpalatal suture opening. Am J Orthod. 1970;58:41-66.

11. Karaman A. I. FAB, I Gelgör, A Demir. Examination of soft tissue changes after rapid maxillary expansion. World J Ortho. 2002;3:217-22.

12. Grayson B, Cutting C, Bookstein FL, Kim H, McCarthy JG. The three-dimensional cephalogram: Theory, technique, and clinical application. Am J Orthod Dentofacial Orthop. 1988;94:327-37.
13. Betts NJ, Vig KW, Vig P, Spalding P, Fonseca RJ. Changes in the nasal and labial soft tissues after surgical repositioning of the maxilla. Int J Adult Orthodon Orthognath Surg. 1993;8:7-23.

14. Guest $E$, Berry E, Morris D. Novel methods for quantifying soft tissue changes after orthognathic surgery. Int J Oral Maxillofac Surg. 2001;30:484-9.

15. Berger JL, Pangrazio-Kulbersh V, Thomas BW, Kaczynski R. Photographic analysis of facial changes associated with maxillary expansion. Am J Orthod Dentofacial Orthop. 1999;116:563-.571.

16. Moss JP. The use of three-dimensional imaging in orthodontics. Eur J Orthod. 2006;28:416-25.

17. Park JU, Hwang YS. Evaluation of the soft and hard tissue changes after anterior segmental osteotomy on the maxilla and mandible. J Oral Maxillofac Surg. 2008;66:98-103.

18. Haas AJ. Palatal expansion: Just the beginning of dentofacial orthopedics. Am J Orthod. 1970;57:219-55.

19. Garib DG, Henriques JF, Janson G, Freitas MR, Coelho RA. Rapid maxillary expansion--tooth tissue-borne versus tooth-borne expanders: A computed tomography evaluation of dentoskeletal effects. Angle Orthod. 2005;75:548-57.

20. Haas AJ. Long-term posttreatment evaluation of rapid palatal expansion. Angle Orthod. 1980;50:189-217.

21. Bishara SE, Staley RN. Maxillary expansion: Clinical implications. Am J Orthod Dentofacial Orthop. 1987;91:3-14.

22. Snodell SF, Nanda RS, Currier GF. A longitudinal cephalometric study of transverse and vertical craniofacial growth. Am J Orthod Dentofacial Orthop. 1993;104:471-83. 